\title{
Development of a Procedural Model of Science Based on Multisensory-Ecology for Early Childhood Education
}

\author{
Yaswinda \\ Department of Early Childhood Education \\ Universitas Negeri Padang \\ Padang, Indonesia \\ yaswinda@fip.unp.ac.id
}

\begin{abstract}
This study aims to develop a procedural model for science based on multisensory-ecology (PSB Mugi) for early childhood education. The study has been conducted on April 2015 until 2017. The method has been used in this research is research and development, which was adapted from the model Borg, Gall and Gall. Data have been collected through observation, interview, and literature study. Data were analyzed descriptively. The Result of the study are, a procedural model of science based on multisensory-ecology. The study concluded that the procedural model of science based on multisensory-ecology can used teacher in kindergarten.
\end{abstract}

Keywords--science; multisensory-ecology; early childhood

\section{INTRODUCTION}

Kindergarten uses the principle of learning through play. But in reality, the time of playing kindergarten children has changed. Kindergarten children spend a lot of time on literacy learning rather than learning through playing and exploring, exercising and using their imaginations. The importance early learning science is that children actively investigate their world through learning by doing, this is the most effective for children to learn. Children can develop skills through their senses through science learning[1]. Teaching science in kindergarten is important because science is an ideal means for developing the minds of children who ask about nature; assisting the implementation of science-literate societies; when exploring science, children will acquire spoken and written language; science teaches children to depreciate the diversity; and encourage children to love science and to be a scientist[2]. The early childhood teachers 'do not have to be expert science teachers'but that they do need to be motivated to provide opportunities for exploration, problem solving, hypothesising, researching, experimenting and investigating in order to support children in their scientific discoveries[3].

Issues associated with environmental education as an emerging area of importance in Early Childhood Education (ECE) are also discussed[4]. Clark's research suggests that education based on ecology is recommended for implementation at all levels of education [5]. Implementation education based on ecology for early childhood can be designed throughout science learning because ideally ecological education is not separated from the children experience in exploring the environment. Ecology-based education will provide space for children to learn actively using multisensory approach. Learning from surrounding environmental sources will encourage children to discover important knowledge and concepts related to different areas of development. The multisensory experience with objects and people in children of environment is the main thing to build children's understanding of their world [6]. Multisensory experience is the starting point of concrete learning and in accordance with the stages of child development.

Yaswinda was published that kindergarten teachers experienced problems in early childhood science learning due to lack of media, facilities and pre-facilities in the early childhood science learning and various understanding the concept of science that exist around the children [7]. For that, they need a model of science on early childhood, media, facilities and pre-facilities in early childhood development are easy and cheap and science learning model contains the concepts of science around the children. Therefore, the researcher is interested to develop the procedural model of science learning based on multisensory-ecology.

\section{METHOD}

The method was used in this research is research and development, which was adapted from the model Borg, Gall and Gall. The method used in this study is a research and development, which, according to Borg and Gall is one of the tools in educational research. The combination of the model Borg and Gall, [8] and Gall, Gall, and Borg, [9] which became the research method shown in Figure 1.

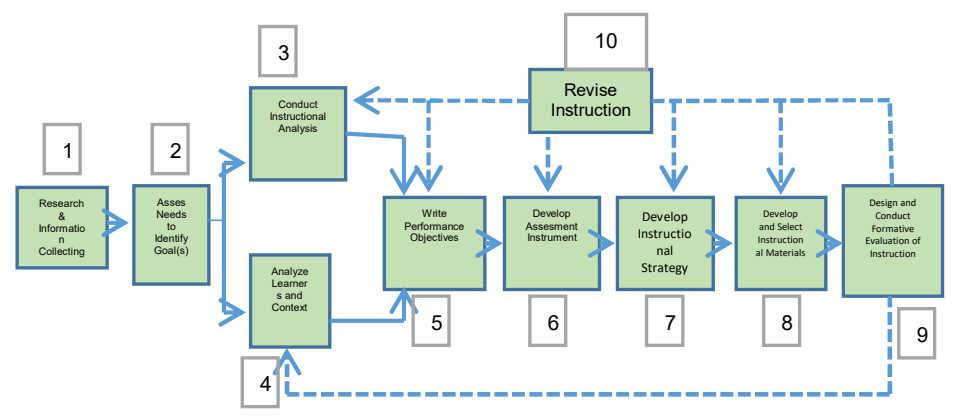

Figure1. The Research Method 
The study has been conducted on April 2015 until 2017. Data were collected through observation, interview, and literature study. Data have been analyzed descriptively

\section{RESULT}

The findings of the study are in two section : (1) a procedural model for science based on multisensory-ecollogy (PSB Mugi) for early childhood education, \{figure 2.\} and (2) the phase of learning science based on multisensoryecolology.

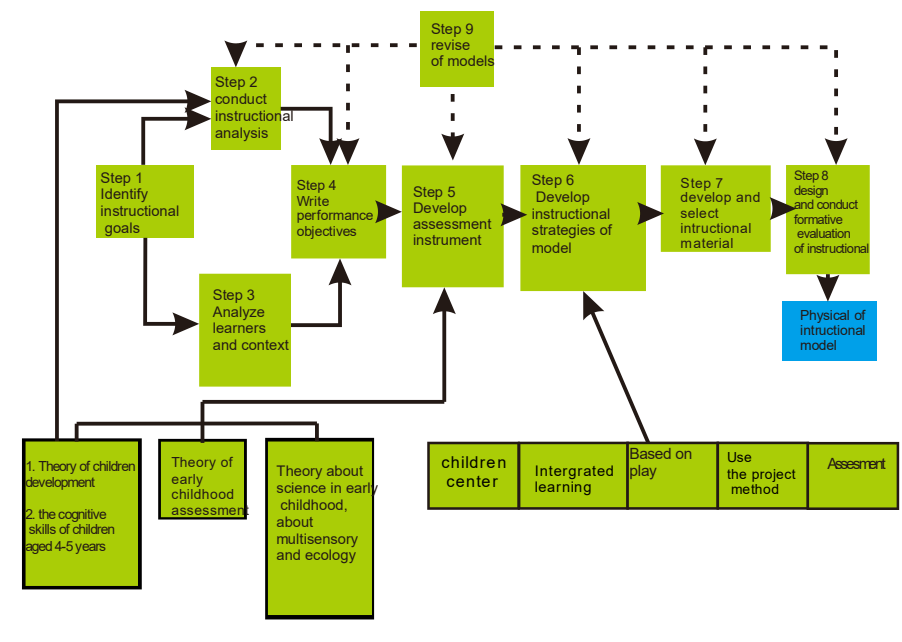

Figure 2. Procedural Instructional Model for Science Based on Multisensory-Ecology (PSB Mugi).

Explanation of the procedural model PSB Mugi as follows; (1) Identify the learning objectives be achieved by determining the general competencies that will be controlled by children after attending the learning derived from theories of child development and child learning science. The purpose of the subject is to improve the cognitive skills of children aged 4-5 years; (2) Conduct analysis of learning, is a procedure used to determine the relevant skills and knowledge required by students to achieve a predetermined competence derived from theories of child development, assessment and learning of science; (3) Identify the early behavior and characteristics of learners, the initial analysis of the behavior and characteristics of the students can be carried out simultaneously in learning situations; (4) Writing performance objectives, this stage of learning objectives should be formulated specifically; (5) Develop an instrument, used to measure the child's success in achieving learning goals, developed from the theories of child development, child assessment and learning science; (6) Develop instructional strategies, the learning strategies developed are arranged so that the learning objectives achieved. This step is in the form of a sequence of instructional activities that can be associated with methods, media, and the time it takes a child to achieve specific learning goals; (7) Develop and select teaching materials; (8) Design and conduct formative evaluation; and (9). Revised program that creates learning programs in the form of physical models.
In this chapter, the result is focused to the result last stage, which Revise instructional model. The revision of the learning model is based on formative tests that have been carried out, the reflection of field formative test records of small groups and large groups. Based on observations and interviews conducted with the teachers found that the time required to implement the learning is relatively long, if the expected results are many. For the purpose of learning is achieved within 90 minutes, the learning objectives to be achieved on each activity are limited to three learning outcomes. This resulted in a revision made from instructional analysis, by selecting an essential indicator in science learning for early childhood education.

This study, science learning based on multisensoryecology strategy is derived based on the theoretical study of ECE science learning, multisensory experience and ecological approach. Preparation of learning strategies based on the learning objectives to be achieved. This learning strategy includes the process of learning activity sequence, outline of content, learning method, media and learning resources used, and the allocation of learning time in thematic learning.

The phase of learning science based on multisensoryecolology consisted four phase.. The process of sequencing of learning activities is only revised at the introduction and closing stages. The initial learning stage consisted of 20 items revised to 18 items with removal of motion and song stage on preliminary activities and stage of motion and song in closing activities. This revision aims to simplify the observation of the implementation of multisensory-ecology learning that emphasizes the linkage of stages with the characteristics of the developmental learning science model. The sequence of revision learning activities becomes 18 items with the following description:

1. Pre-Introduction phase consists of the preparation phase of the media and learning resources and preparation of waste arrangements which include activities: (1) preparation of RKH; (2) media preparation; (3) preparation of the learning environment; (4) and preparation of waste management.

2. Introduction phases that include the phases: (1) reading titles and prayers; (2) explanation of activity objectives; and (3) organizing children.

3. Learning phase consists of core learning phase and waste management covering activities: (1) Learning science that supports children to explore; (2) science learning that emphasizes process skills; (3) Science learning supports the use of more than two senses; (4) Science learning uses more than two instructional media; (5) The existence of interaction with the environment (biotic and abiotic); (6) The existence of activities to reduce earth damage; and (7) waste management in learning.

4. Finally phase, includes a phase of the circle of appearance, strengthening of understanding and display of works include activities: (1) appearance circle; (2) question and answer activities; (3) strengthening understanding; (4) and display works. The content and learning methods are not revised. 


\section{DISCUSSION}

The model is a representation of reality that describes the structure and order of a concept as one of four forms: (1) a verbal or conceptual description; (2) procedural; (3) physical or visual replicas; and (4) equations or formulas[10]. The design of the procedural model of science learning PSB Mugi in this study was developed based on the work stages as in the development design recommended by Dick, Carey and Carey that modified. This ten-step model is known as The Systematic Design of Instructional [11]. Procedural model is a model that describes the flow or procedural steps that must be followed gradually to produce a certain product.

When developing a learning strategy, media planning is prepared by prioritizing the creation of self-learning media by teachers who are mostly used materials, or natural materials or waste materials. This is in line with the principle of learning PSB Mugi model number five is doing activities that can reduce earth damage[12]. In addition, the media is also easy to create and can be used again for another class study group. Benefits obtained is to save the budget to buy learning media.

Based on the research findings obtained three main things that need to be considered by the teacher to apply sciencebased on multisensory-ecology for children kindergarten, that is: preparation of study rooms, guide the children in learning, and preparation of learning media that can stimulate multisensory students. This is in line with Eliason and Jenkins[13], children are naturally interested in using their senses to explore the world, by touching, pinching, feeling, licking, chewing, kissing, watching, and listening to things. Children learn to use their senses appropriately, so they become more environmentally conscious and use reason to build concepts. Learning science in kindergarten must consider learning with multisensory approach. The multisensory approach bases on the assumption that the child will be able to learn well when the teaching materials are presented in the modalities of the sensory apparatus including visual, hearing, touch, touch and taste.

Children need to gain a multisensory experience in science learning is a neuroscience implication that became the issue of twentieth century education trends. Science learning in kindergarten must consider the time children use as active learners and the implications of neuroscience, to learn by using their multisensory, visually, auditory, kinesthetic (touch and balance), gustatory, and olfactory.

Intructional models of learning science based on mutisensory-ecology consists seven phase of core learning phase and waste management covering activities: (1) Learning science that supports children to explore; (2) science learning that emphasizes process skills; (3) Science learning supports the use of more than two senses; (4) Science learning uses more than two instructional media; (5) The existence of interaction with the environment (biotic and abiotic); (6) The existence of activities to reduce earth damage; and (7) waste management in learning. That is line with the reseach of Okul ect [14], they beliaved that early childhood science education would help children understand the happenings around, meet the curiosity, provide a basis for their later.

\section{CONCLUSION}

It can be concluded that the instructional procedural of the science model based on multisensory-ecological consist ten steps. Results of procedural model can as reference to implement this model in a different kindergarten. The conclusion of this study has implications as follows: procedural model of science based on multisensory-ecology be one option for teachers to implement the model of science learning for early childhood education.

The advantages of the PSB Mugi procedural model among others, are the learning media used in this model is mostly used materials, or natural materials or waste materials that save the budget to buy learning media. In addition, the media is also easy to create and can be used again for another class study group. Recommendations for further research needs to be set up the physical model on science based on multisensory-ecology should be studied seriously by Kindergaten teachers .

\section{Acknowledgment}

In this moment I would like to thank Mrs. Prof. Dr.Yufiarti, M.Psi from Universitas Negeri Jakarta and Prof. Dr. Atwi Suparman, M.Sc. from Open University of Indonesia. Financial support from the FIP and LP2M Universitas Negeri Padang very helpful publication of this article.

\section{References}

[1] Mayesky, Creative Activites for Young Children, 10th ed. Wasworth: Cengage Learning, 2012.

[2] M. GS, Fundamentals of Early Childhood Education (ECD)., 5th ed. Jakarta: Indeks, 2011.

[3] F. O'Brien and S. Herbert, "Colour, magnets and photosynthesis," Australas. J. Early Child., vol. 40, no. 1, pp. 42-46, 2015.

[4] H. Cutter-Mackenzie, Amy; Edwards, Suzy; Gough, Annette; Gough, Noel; Whitehouse, "Environmental education; Early childhood education," Aust. J. Environ. Educ., vol. 30, no. 1, pp. 127-133.

[5] C. K.E., "Ecological Intelligence and Sustainability Education in Special Education Multicultural Education," vol. 21, no. 1, p. 38, 2013.

[6] H. M.L., Henniger, M.L. Teaching Young Children An Introduction, , Boston: , 2013le, 5th Editio. Boston: Pearson, 2013.

[7] Yaswinda, The Problem of Early Childhood Science Learning, in Proceedings of Padang: Padang: International Conference on Early Childhood Education. Faculty of Education ,PG PAUD UNP, 2012.

[8] M. D. G. and W. R. Borg, Educational Research., 4th ed. New York: Longman, 1983.

[9] W. R. Gall,Meredith D.; Gall, Joyce P and Borg, Educational Research, 8th Edition. Boston: Pearson Edu, 2007., 8th ed. Boston: Pearson Edu, 2007.

[10]M. A. Suparman, Modern Instructional Design (MPI), 4th ed. jakarta: Publisher Erlangga, 2014. 
[11] and J. O. C. Dick, Walter; Carey, Lou and James O. CareyWalter Dick, Lou Carey, The Systematic Design of Instruction, Seventh. New Jersey: Pearson Education Inc, 2009.

[12] Yaswinda, "Science Learning Model Based on Multisensory-Ecology in Early Childhood Education: A Conceptual Model," in Proceedings of the 3rd International Conference on Early Childhood Education (ICECE 2016), 2017, pp. 463-468.

[13]L. A. Eliason, Claudia and Jenkins, Practical Guide to Early Childhood Curriculum, Eight Edit. New Jersey: Pearson Edu, 2008.

[14]A. Y. Türkoğlu, S. Üniversitesi, E. Fakültesi, F. Bilimleri, and E. Bölümü, "Use of Models in Early Childhood Science Education 1 Okul Öncesi Fen Eğitiminde Model Kullanımı,” no. 5, pp. 1995-2007, 2017. 